\title{
CYTOTOXIC AND PHYTOCHEMICAL INVESTIGATION OF COUSINIA ERMENEKENSIS HUB.-MOR.
}

\author{
LEYLA PAŞAYEVA $^{1 *}$, EREN DEMIRPOLAT ${ }^{2}$, HANIFA FATULLAYEV $^{3}$, OSMAN TUGAY $^{4}$ \\ ${ }^{1}$ Department of Pharmacognosy, Faculty of Pharmacy, Erciyes University, Kayseri 38030, Turkey \\ ${ }^{2}$ Department of Pharmacology, Faculty of Pharmacy, Erciyes University, Kayseri 38030, Turkey \\ ${ }^{3}$ Department of Pharmaceutical Chemistry, Faculty of Pharmacy, Erciyes University, Kayseri 38030, Turkey \\ ${ }^{4}$ Department of Pharmaceutical Botany, Faculty of Pharmacy, Selçuk University, Konya 42250, Turkey
}

*corresponding author: leylapasayeva@hotmail.com

Manuscript received: November 2018

\begin{abstract}
Cousinia is one of the widespread genera of Asteraceae family. There are numerous studies on this genus and it has not been examined phytochemically in detail. Thus, we aimed to evaluate the phytochemical composition and the cytotoxic effect of Cousinia ermenekensis on human lung cancer (A549), human colon adenocarcinoma (Colo 205), hepatocellular carcinoma (HepG2) cell lines and human bronchial epithelial (Beas-2b) cell line. C. ermenekensis methanol extract showed higher cytotoxic activity against Colo 205 cell line $\left(\mathrm{IC}_{50}=69 \mu \mathrm{g} / \mathrm{mL}\right.$ ). A preliminary examination of the mass spectrums revealed the presence of 13 compounds in the extract. According to the quantitative analyses, the highest content of chlorogenic acid, malic acid, quinic acid and, rutin were detected in extract $(28.496,18.264,15.115$ and $12.506 \mu \mathrm{g} / \mathrm{mg}$ extract respectively).
\end{abstract}

\section{Rezumat}

Cousinia este unul dintre genurile cele mai răspândite din familia Asteraceae, existând numeroase studii asupra acestui gen, dar fără a prezenta detalii fitochimice. Studiul de față prezintă compoziţia fitochimică şi efectul citotoxic al speciei Cousinia ermenekensis asupra cancerului pulmonar uman (A549), adenocarcinomului de colon uman (Colo 205), carcinomului hepatocelular (HepG2) și liniilor de celule epiteliale bronșice umane (Beas-2b). Extractul metanolic de C. ermenekensis a prezentat activitate citotoxică superioară asupra liniei celulare Colo $205\left(\mathrm{IC}_{50}=69 \mu \mathrm{g} / \mathrm{mL}\right)$. O evaluare preliminară a spectrelor de masă a evidențiat prezența a 13 compuși în extract. Conform analizelor cantitative, au fost detectate, în concentrație ridicată, acid clorogenic, acid malic, acid chinic și rutină $(28,496 ; 18,264 ; 15,115$ și, respectiv, $12,506 \mu \mathrm{g} / \mathrm{mg}$ extract).

Keywords: Cousinia, Asteraceae, cytotoxicity, LC-MS/MS

\section{Introduction}

Cancer is a disease that starts when cells grow out of control and crowd out normal cells in any place in the body. There are many types of cancer, that take place in the lungs, the breast, the colon or in the blood. Cytotoxicity is the inhibition of the uncontrolled growth of cells [7]. Because of their side effects and interactions, synthetic drugs are not preferred in the treatment of different cancer types. However, in the recent years, the use of herbal medicines has been increasing due to their therapeutic activity and low toxicity [5].

The members of the Asteraceae family (syn. Compositae) were used in the treatment of various cancer types [4]. Cousinia Cass. is one of the most diverse genera of the Asteraceae family. This genus consists of $600-$ 700 species distributed in Central and South-West Asia and is represented by 38 species and 6 sections in Turkey. C. ermenekensis Hub.-Mor. is endemic in Turkey and could be seen in open areas and scrublands in Karaman. This a biennial plant, with spiny-dentate leaves and pink, purple or rose flowers. The flowering period of the plant is July [9].

In the literature, taxonomic and systematic studies are generally performed on the genus of Cousinia, but phytochemical and activity studies are rarely seen. Thus, we aimed to investigate the phytochemical and biological properties of the species. In this study, the cytotoxic effect of this species was screened on human lung cancer (A549), human colon adenocarcinoma (Colo 205), hepatocellular carcinoma (HepG2) cell lines and human bronchial epithelial (Beas-2b) cell line and phytochemical profile of extract and quantitative analyses of phenolic compounds were determined by LCMS/MS.

\section{Materials and Methods}

Plant material and preparation of extracts The flowering aerial parts of $C$. ermenekensis were harvested from East Ermenek, Karaman in July 2013 and identified by Prof. Dr. Osman Tugay. This specimen was stored at the Herbarium of Selçuk University (Voucher No. 1, KNYA 26.976). 
FARMACIA, 2020, Vol. 68, 3

Air-dried aerial parts of C. ermenekensis (500 g) were powdered and extracted three times with methanol by maceration, at room temperature. Combined macerates were filtered and evaporated to dryness under reduced pressure at $37^{\circ} \mathrm{C}$ using a rotary evaporator. The crude extracts were stored in dark at $-20^{\circ} \mathrm{C}$. The yield of extract was $10 \%$.

Qualitative and quantitative $L C-M S / M S$ assay

LC-MS/MS instrumentation

The quantitative and qualitative analyses were performed by using liquid chromatography-electrospray ionizationmass spectrometry/mass spectrometry (LC-ESI-MS/MS, Shimadzu 8040). The mass spectrometric behaviour of extract was studied using the negative-ion mode. The sample was prepared in methanol and was injected $(1 \mu \mathrm{L})$ into the LC-MS/MS equipped with a C18 reverse-phase column ( 150 x $4.6 \mathrm{~mm}$ x $3 \mu \mathrm{m}$; Restek). A mixture of methanol: formic acid $(99: 1 \mathrm{v} / \mathrm{v})(\mathrm{A})$ and water: formic acid (99:1, v/v) (B) was selected as mobile phase. The mobile phase consisted of $90 \%$ solvent $\mathrm{A}$ and $10 \%$ solvent $\mathrm{B}$ at a flow rate of 0.4 $\mathrm{mL} / \mathrm{min}$.

In vitro cytotoxic activity assay

A549, Colo205, HepG2, and Beas-2b were cultured in RPMI medium (Sigma R8758) supplemented with 10\% FBS (Biochrome S0415) and $100 \mathrm{U} / \mathrm{mL}$ penicillin$100 \mathrm{ug} / \mathrm{mL}$ streptomycin (Sigma P4333). 10.000 cells were dispensed to 96 well plates in $100 \mu \mathrm{L}$ medium and incubated overnight. The extract was dissolved in dimethylsulfoxide (DMSO, Applichem A3672) in order to obtain $3 \mathrm{mg} / \mathrm{mL}$ stock solutions of extracts which contains $1.5 \%$ DMSO. 125, 250, 500, 750, $1000 \mu \mathrm{g} / \mathrm{mL}$ extract concentrations were prepared two times by diluting stock solutions with the medium. Then, extracts were added to cultures in $100 \mu \mathrm{L}$ volume. To obtain a homogenous solution, plates were incubated on a plate shaker for 5 minutes and further incubated at $37^{\circ} \mathrm{C}$ under a humidified atmosphere of $5 \% \mathrm{CO}_{2} .24 \mathrm{~h}$ later, cell viability was determined by SRB assay [25].

Statistical Analysis

All data were calculated by using Systat Sigma Plot (ver. 12.0) software and a One-way ANOVA post hoc Dunnett test was used to determine the statistical significance $\left({ }^{*} p<0.05\right)$ in cytotoxicity tests.

\section{Results and Discussion}

Qualitative LC-MS/MS analyses of phenolic compounds The identification of phenolic compounds in the CE extract was evaluated based on the accurate mass, the registered mass spectra fragmentation patterns, and literature data. Compounds were studied in the negative ion mode and total ion chromatograms (TIC) of the extract are presented in Figure 1. A preliminary examination of the mass spectrums revealed the presence of 13 compounds in the methanolic extract (Table I). The mass spectra of CE extract are presented in Figure 2.

Table I

Mass spectral characteristics and identity of compounds in Cousinia ermenekensis extract

\begin{tabular}{|c|c|c|c|c|}
\hline $\begin{array}{c}\text { Pik } \\
\text { No }\end{array}$ & $\begin{array}{c}\mathbf{R T} \\
\mathbf{t}_{\mathbf{R}}(\mathbf{m i n})\end{array}$ & {$[\mathbf{M}-\mathbf{H}]^{-}(\mathbf{m} / \mathbf{z})$} & $\begin{array}{c}\text { MS/MS } \\
(\mathbf{m} / \mathbf{z})\end{array}$ & Compounds \\
\hline 1 & 3.2 & 461 & 285 & Luteolin 7-O-glucuronide [17] \\
\hline 2 & 3.8 & 269 & $269,183,159,151,149,117,107,83,65$ & Apigenin [20] \\
\hline 3 & 4.3 & 377 & $341,215,179,161,119$ & Caffeic acid derivative [18] \\
\hline 4 & 4.9 & 341 & $179,161,683$ & Dicaffeic acid [3] \\
\hline 5 & 5.1 & 191 & $191,93,85$ & Quinic acid [8] \\
\hline 6 & 5.3 & 353 & $191,179,173,135$ & Chlorogenic acid [16] \\
\hline 7 & 5.6 & 179 & 135,87 & Caffeic acid [12] \\
\hline 8 & 7.2 & 133 & 115,71 & Malic acid [11] \\
\hline 9 & 8.1 & 609 & 301 & Rutin [14] \\
\hline 10 & 10.2 & 623 & 315 & Isorhamnetin 3- $O$-rutinoside [16] \\
\hline 11 & 14.1 & 317 & - & Myricetin [10] \\
\hline 12 & 14.2 & 387 & $223,191,179$ & Myricitrin- $O$-gallate [1] \\
\hline 13 & 17.5 & 615 & $469,393,317,169$ & \\
\hline
\end{tabular}

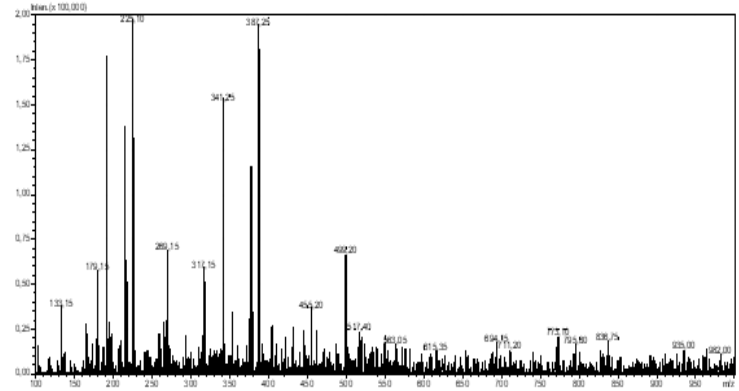

Figure 1.

TIC profile of Cousinia ermenekensis extract

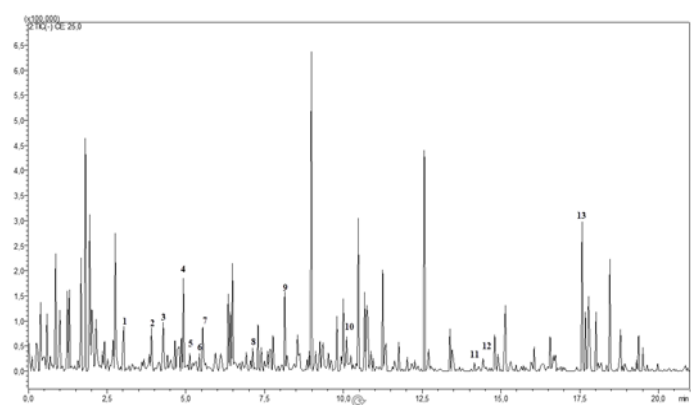

Figure 2.

Mass spectra of Cousinia ermenekensis extract 
This is the first report about the phenolic composition of $C$. ermenekensis. Based on chemical reports on some Cousinia species, various chemical compounds including steroids, triterpenes, sesquiterpene lactones and flavonoids were declared [13, 19, 23, 24]. To the best of our knowledge, only one study reported data about the phenolic composition of Cousinia verbascifolia identifying apigenin and caffeic acid as the phenolic compounds [22].

Quantitative Analyses of Compounds Optimization of LC-MS/MS condition

The mass spectrometric behaviour of compounds was studied using both positive-ion and negative-ion mode. Negative-ion mode provided a superior sensitivity for these compounds due to more efficient ionization, simpler fragmentation, and lower baseline noise. These compounds were subsequently analysed in Q1Scan (Product Ion Scan) mode, using $[\mathrm{M}-\mathrm{H}]^{-}$ ions as precursors. Obtained MS2 spectra were used to select the optimal product ions. The MRM parameters, such as the precursor ion $\mathrm{m} / \mathrm{z}$, collision energy, and product ion $\mathrm{m} / \mathrm{z}$ for compounds were optimized by an automatic MRM optimization function. The obtained
LC-MS/MS chromatogram and mass spectrum of compounds are presented in Figure 3.

Preparation of standard and sample solutions

Stock solutions of compounds were prepared in methanol at $8 \mu \mathrm{g} / \mathrm{mL}$ concentrations. The extract solutions were prepared in methanol at $10 \mu \mathrm{g} / \mathrm{mL}$.

The quantitative results of the compounds are given in Table II. As shown in the table, the main compounds of $\mathrm{CE}$ were chlorogenic acid, malic acid, quinic acid and rutin with the highest content $(28.496,18.264$, 15.115 and $12.506 \mu \mathrm{g} / \mathrm{mg}$ extract respectively). This is the first report regarding the quantitative analyses of phenolic compounds in Cousinia species.

Table II

Compounds in Cousinia ermenekensis extract

\begin{tabular}{|l|c|c|}
\hline \multicolumn{1}{|c|}{ Constituent } & $\begin{array}{c}\text { RT } \\
(\mathbf{m i n})\end{array}$ & $\begin{array}{c}\text { Content }^{\mathrm{a}} \\
(\mu \mathrm{g} / \mathrm{mg} \text { extract })\end{array}$ \\
\hline Malic acid & 7.2 & $18.264 \pm 0.058$ \\
\hline Caffeic acid & 5.6 & $1.248 \pm 0.004$ \\
\hline Quinic acid & 5.1 & $15.115 \pm 0.027$ \\
\hline Chlorogenic acid & 5.3 & $28.496 \pm 0.055$ \\
\hline Rutin & 8.1 & $12.506 \pm 0.012$ \\
\hline Isorhamnetin 3- $O$-rutinoside & 10.2 & $1.727 \pm 0.112$ \\
\hline \multicolumn{2}{|l|}{ RT-retention time, ${ }^{a}$ Mean \pm SD $(\mathrm{n}=3)$}
\end{tabular}
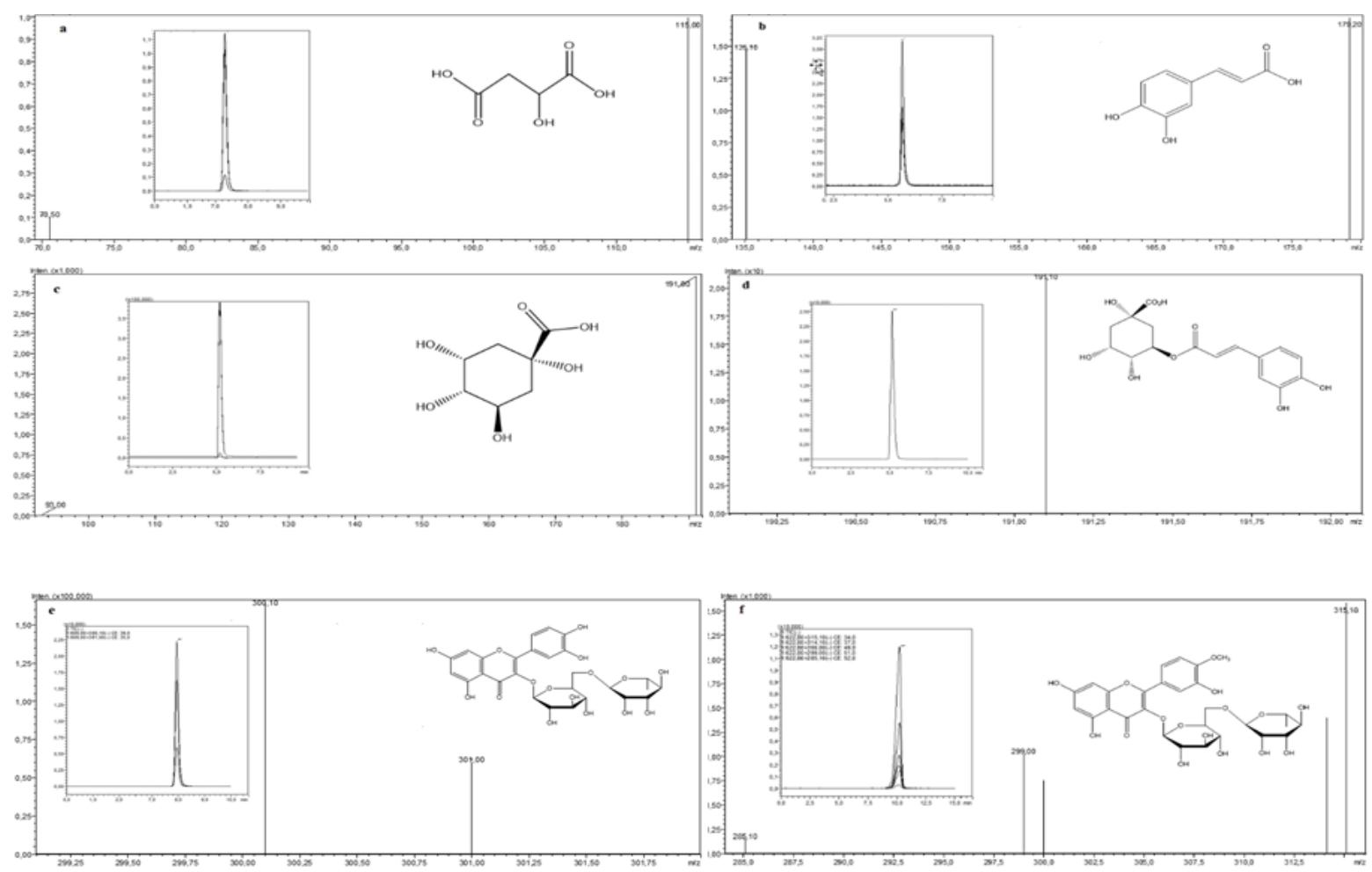

Figure 3.

LC-MS/MS chromatogram and mass spectra of malic acid (a), caffeic acid (b), quinic acid (c), chlorogenic acid (d), rutin (e) and isorhamnetin 3-O-rutinoside (f)

In vitro cytotoxic activity

The cytotoxicity of the methanolic extract of $C$. ermenekensis was investigated against A549, Colo205, HepG2 cancer cell lines and Beas-2b cell line by SRB method. Results showed that CE extract (1000, 750, $500,250,125 \mu \mathrm{g} / \mathrm{mL}$ ) was more cytotoxic against particularly Colo205 cancer cell line with the 69 $\mu \mathrm{g} / \mathrm{mL} \mathrm{IC}_{50}$ value (Table III). As shown in the table, CE extract is not toxic to A549 and HepG2 cancer cell lines. Additionally, this extract was the least toxic to Beas-2b (Figure 4). In a previous study, the effects of ethanol extracts of some Cousinia species on 
different cancer cell lines and matrix metalloproteinase protein (MMP) inhibitor effects were examined. The cytotoxic activity of ethanol extracts from different Cousinia species was investigated against fibrocarcinoma cell line and $C$. verbasciflora have shown higher cytotoxic activity with $18.4 \pm 0.59 \mu \mathrm{g} / \mathrm{mL} \mathrm{IC}_{50}$ value [23]. In another study, sesquiterpene compounds, namely desoxyjanerin and raserolit, obtained from the dichloromethane extract of $C$. aitchisonii, were subjected to the cytotoxic screening on five different cell lines. As a result, both compounds showed significant cytotoxic effect on breast cancer MCF-7 cell line $\left(\mathrm{IC}_{50}=4.5 \mu \mathrm{g} / \mathrm{mL}\right.$ and $4.6 \mu \mathrm{g} / \mathrm{mL}$, respectively) [13]. Additionally, the MMP inhibitory effect of $C$. shulabadensis was investigated and reported to have a considerable inhibitory effect $\left(\mathrm{IC}_{50}=49.2 \pm 0.51 \mu \mathrm{g} / \mathrm{mL}\right)$ [23].

Our results are in agreement with the previously reported. So, we can affirm that $C$. ermenekensis has selective cytotoxic activity because it is not cytotoxic to Beas- $2 \mathrm{~b}$ and no $\mathrm{IC}_{50}$ can be detected. Some of the identified substances in the extract already were known for their anticancer properties. Numerous studies have reported anticancer properties for apigenin [15], caffeic acid, chlorogenic acid, quinic acid [21], luteolin-7-Oglucuronide, myricetin $[2,6]$ through various mechanisms. According to these results, we can consider that the potent cytotoxic activity of CE on the Colo205 cell line may be explained with the presence of these anticancer flavonoid compounds.

Table III

In vitro $24 \mathrm{~h}$ cytotoxicity of the methanol extract of Cousinia ermenekensis

\begin{tabular}{ccccc}
\hline \multicolumn{4}{c}{ IC $_{50}(\mu \mathrm{g} / \mathrm{mL})$} \\
Cell line \\
\hline \multirow{2}{*}{ CE } & $\mathbf{A 5 4 9}$ & Colo 205 & HepG2 & Beas-2b \\
& In & 69 & 780 & In \\
\hline
\end{tabular}

A549, human lung carcinoma; Colo 205, human colorectal adenocarcinoma; HepG2, human hepatocarcinoma; Beas-2b bronchial epithelial cell line; In, inactive; CE: C. ermenekensis
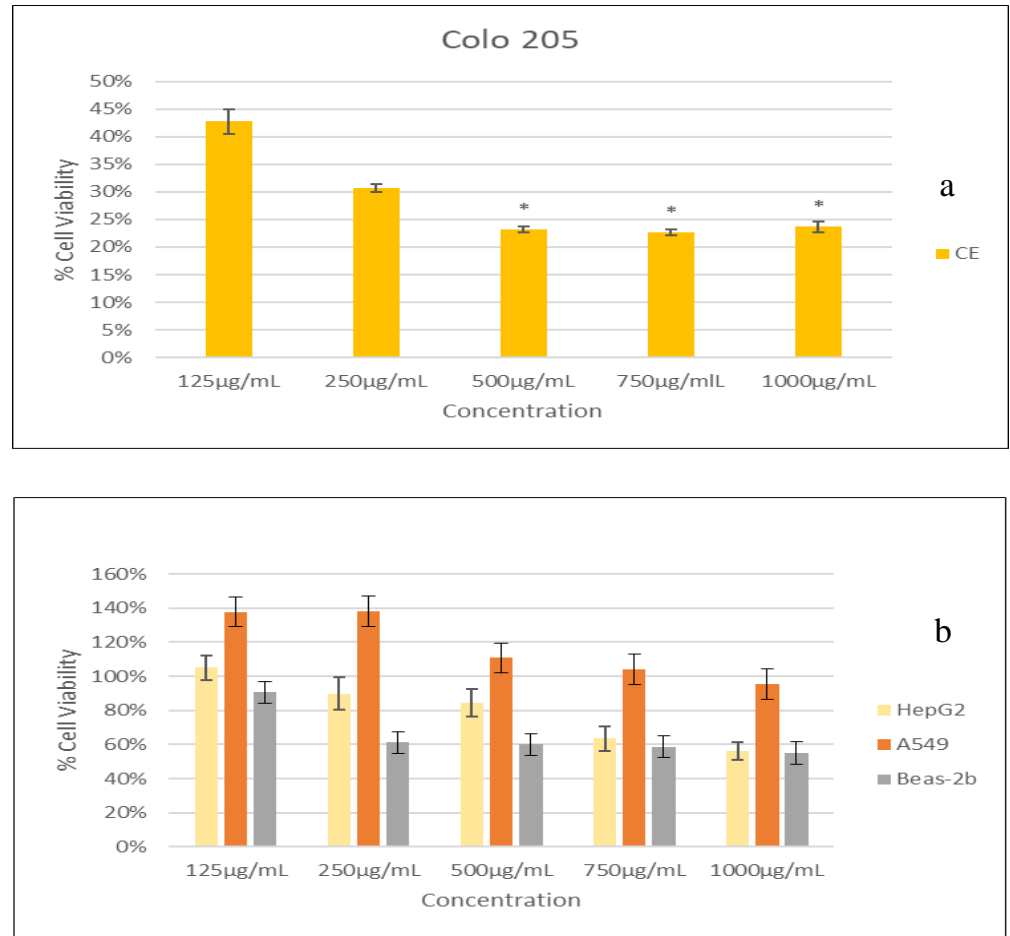

Figure 4.

Cell viability at the end of $24 \mathrm{~h}$ incubation with Cousinia ermenekensis extract a. Colo 205; b. HepG2, A549,

Beas- $2 \mathrm{~b}$

Mean values of groups are statistically different $(\mathrm{p}<0.001)$. Mean values of the treatment groups are statistically different than the control group. (*p < 0.05). A549, human lung carcinoma; Colo 205, human colorectal adenocarcinoma; HepG2, human hepatocarcinoma; Beas-2b bronchial epithelial cell line; CE: C. ermenekensis

\section{Conclusions}

This is the first report on the phytochemical characterization and cytotoxic activity of $C$. ermenekensis. Moreover, investigation of the cytotoxic properties and identification and quantification of some phenolics in this species will promote advanced studies that may help to protect against free radical damage and oxidative stress-related diseases. Furthermore, this preliminary research suggests a detailed investigation to isolate and elucidate structures of the bioactive compounds, which are responsible for cytotoxic activity.

\section{Conflict of interest}

The authors declare no conflict of interest. 


\section{References}

1. Abu-Reidah IM, Ali-Shtayeh MS, Jamous RM, ArráezRomán D, Segura-Carretero A, HPLC-DAD-ESIMS/MS screening of bioactive components from Rhus coriaria L. (Sumac) fruits. Food Chem., 2015; 166: 179-191.

2. Batra P, Sharma AK, Anti-cancer potential of flavonoids: recent trends and future perspectives. 3 Biotech., 2013; 3(6): 439-459.

3. Bravo L, Goya L, Lecumberri E, LC/MS characterization of phenolic constituents of mate (Ilex paraguariensis, St. Hil.) and its antioxidant activity compared to commonly consumed beverages. Food Res Int., 2007; 40(3): 393-405.

4. Campos KC, Rivera JH, Gutierrez JR, Rivera IO, Velez AC, Torres MP, Ortiz MP, Millán CAO, Biological screening of select Puerto Rican plants for cytotoxic and antitumor activities. P R Health Sci J., 2015; 34(1): 25-30.

5. Carvalho CC, Machado KN, Ferreira PMP, Pessoa C, Fonseca THS, Gomes MA, Nascimento AM, Biological screening of extracts of Brazilian Asteraceae plants. Afr J Pharm Pharmacol., 2013; 7(28): 2000-2005.

6. Chahar MK, Sharma N, Dobhal MP, Joshi YC, Flavonoids: A versatile source of anticancer drugs. Pharmacogn Rev., 2011; 5(9): 1-12.

7. Chambers AF, Groom AC, MacDonald IC, Metastasis: dissemination and growth of cancer cells in metastatic sites. Nat Rev Cancer, 2002; 2(8): 563-572.

8. Clifford MN, Johnston KL, Knight S, Kuhnert N, Hierarchical scheme for LC-MS n identification of chlorogenic acids. J Agric Food Chem., 2003; 51(10): 2900-2911.

9. Davis P. H and A. Huber M, Vol. 5. Cousinia in flora of Turkey and the East Aegean Islands. Edinburgh University Press, Edinburgh, 1975.

10. de Brito ES, de Araújo MCP, Lin L-Z, Harnly J, Determination of the flavonoid components of cashew apple (Anacardium occidentale) by LC-DAD-ESI/MS. Food Chem., 2007; 105(3): 1112-1118.

11. González RR, Fernández RF, Vidal JLM, Frenich AG, Pérez MLG, Development and validation of an ultra-high performance liquid chromatography-tandem mass spectrometry (UHPLC-MS/MS) method for the simultaneous determination of neurotransmitters in rat brain samples. J Neurosci Methods, 2011; 198(2): 187-194.

12. Horai H, Arita M, Kanaya S, Nihei Y, Ikeda T, Suwa K, Ojima Y, Tanaka K, Tanaka S, Aoshima K, MassBank: a public repository for sharing mass spectral data for life sciences. J Mass Spectrom., 2010; 45(7): 703-714.

13. Iranshahy M, Tayarani-Najaran Z, Kasaian J, Ghandadi M, Emami SA, Asili J, Chandran JN, Schneider B, Iranshahi M, Highly oxygenated sesquiterpene lactones from Cousinia aitchisonii and their cytotoxic properties: rhaserolide induces apoptosis in human T lymphocyte (Jurkat) cells via the activation of c-Jun n-terminal kinase phosphorylation. Phytother Res., 2016; 30(2): 222-226.

14. Karaçelik AA, Küçük M, İskefiyeli Z, Aydemir S, De Smet S, Miserez B, Sandra P, Antioxidant components of Viburnum opulus L. determined by on-line HPLCUV-ABTS radical scavenging and LC-UV-ESIMS methods. Food Chem., 2015; 175: 106-114.

15. Lefort ÉC, Blay J, Apigenin and its impact on gastrointestinal cancers. Mol Nutr Food Res., 2013; 57(1): 126-144.

16. Lin L-Z, Harnly JM, Identification of the phenolic components of the chrysanthemum flower (Chrysanthemum morifolium Ramat). Food Chem., 2010; 120(1): 319-326.

17. Lin LZ, He XG, Lindenmaier M, Nolan G, Yang J, Cleary M, Qiu SX, Cordell GA, Liquid chromatographyelectrospray ionization mass spectrometry study of the flavonoids of the roots of Astragalus mongholicus and A. membranaceus. J Chromatogr A, 2000; 876 (1-2): 87-95.

18. Maoka T, Fujiwara Y, Hashimoto K, Akimoto N, Rapid Identification of carotenoids in a combination of liquid chromatography/UV-visible absorption spectrometry by photodiode-array detector and atomospheric pressure chemical ionization mass spectrometry (LC/PAD/APCI-MS). J Oleo Sci., 2002; 51(1): 1-9.

19. Marco JA, Sanz JF, Albiach R, Rustaiyan A, Habibi $\mathrm{Z}$, Bisabolene derivatives and sesquiterpene lactones from Cousinia species. Phytochemistry, 1993; 32(2): 395-400.

20. Prasain JK, Wang C-C, Barnes S. Mass spectrometric methods for the determination of flavonoids in biological samples. Free Radic Biol Med., 2004; 37(9): 1324-1350.

21. Rocha LD, Monteiro MC, Teodoro AJ, Anticancer properties of hydroxycinnamic acids-A review. Cancer Clinic Oncol., 2012; 1(2): 109-121.

22. Sajjadi SE, Ghanadian M, Haghighi M, Isolation and identification of two phenolic compounds from a moderately cytotoxic fraction of Cousinia verbascifolia Bunge. Adv Biomed Res, 2017; 6: 66.

23. Shahverdi AR, Khoramizadeh MR, Ghahramani MH, Golyaee A, Attar F, Ghahraman A, Chemopreventive effect of Cousinia shulabadensis Attar \& Ghahraman ethanol extract. Afr Jf Tradit Complem Alter Med., 2007; 4(1): 12-16.

24. Ulubelen A, Tuzlaci E, Flavonoids and terpenoids from Cousinia eriosephala. Fitoterapia, 1988; 59: 350.

25. Vichai V, Kirtikara K, Sulforhodamine B colorimetric assay for cytotoxicity screening. Nat Protoc., 2006; 1(3): 1112-116. 